\title{
Metamorphosis as Fantasy of the Hybrid. Postmodern Horror and the Destiny of the Human Body in The Fly (David Cronenberg, 1986)
}

\author{
Vicente Sánchez-Biosca'
}

\section{Sorcerers and Scientists}

The scientists we became accustomed to in fantastic and horror films were indelibly endowed with a romantic seal: they were men whose discoveries had driven them mad. These discoveries inevitably breached the borderline of what was forbidden to mankind and they were diabolically tempted to conquer the power that would turn them into gods, alchemists of creation, sorcerers far beyond the principles of modern science. For them, and for the narrative that situated them, science was not a set of postulates external to the subjects who applied them. In fact, they did not separate themselves from the system. In other words, the desire of these characters was not separate from their science; it was rather their only, and fiercest, drive. A passionate science, we might say, aware of the contradiction in terms. Perhaps for this reason the first destiny of science in fantastic films ended up in the hands of animism, or more precisely, in the vacillations that for our scientific mind always awakens what Claude Lévi-Strauss called, ironically referring to his critics, "savage thought." While horror films showed a predilection for animist type myths (the wolf man, the panther woman in Cat People-Jacques Tourneur, 1942, or Count Dracula) over those in which science took on a certain importance (Frankenstein-James Whale, 1931, The Man Who Changed His MindRobert Stevenson, 1936, Doctor Jekyll and Mr. Hyde-Rouben

\footnotetext{
'Translated from the Spanish by Susan Hoover.

2 "Une science du concret" in La pensée sauvage, Paris, Plon, 1962. See also chapters of Myth and Meaning, University of Toronto Press, 1978. This is similar to what Freud called "das Unheimliche" (the uncanny) in his famous text of 1919.
} 
- "History and the study of culture." New Literary History, v. 21, № 2, winter 1990: 407-20.

Vattimo, Gianni. El fin de la modernidad: Nihilismo y hermenéutica en la cultura postmoderna. Trans. A. Bixio. Barcelona: Gedisa, 1990. 
Mamoulian, 1932, etc.), this second type of film typically presented science as archaic, telluric or magical, hence bringing these films closer to the first type. ${ }^{3}$

Today fantastic, science fiction and horror films are taking an unsuspected turn. They seem to have become obsessed with the human body; not with its beauty or aura (as in Classical cinema) but with its destruction, its being torn apart, with the violence it is capable of withstanding, even beyond death. This attitude runs parallel to an appeal to the authority of disciplines such as physiology, anatomy, and forensic medicine..., but also, and above all, to biology, specifically genetics.

\section{The Shadow line and the Body}

It is the aim of this essay to inquire into an overlapping - a shady area, which is the object of fiction in recent horror films, namely: that which is situated between the image of the human body on the one hand, and biology and genetics on the other. Along with the mutilations, murders, visual explosions of blood and guts, constant metamorphoses, genetic deformations and viral invasions, there is also an attempt to make unascertainable the identity of this surprising machine-so close and yet so unknown - that is the human body. It is as if the unified Gestalt, the only coherent image we can perceive, were torn apart in these fictions, ripped into unrecognizable parts. But there is something else: a variation of these films turns to genetics - not so much for an intriguing and novel base for plots, nor for the ensuing preciseness in verisimilitude, as much as for a place in which to unfold fantasies.

Let us clarify: it is not our aim to maintain that modern cinema is especially concerned with the progress of science, but rather that it reveals the scientific imaginary belonging to the so-called postmodernity in which certain relations that were previously concretely codified have now become clouded: the old and the young, masculine and feminine, the living and the dead, animal and human. A brief digression will perhaps help us to

\footnotetext{
${ }^{3}$ The so-called German Expressionism was exemplary in this respect, by delving into the Hebraic matrix of alchemists who experimented with the most esoteric and hermetic sciences possible: the Rabbi Löw in The Golem (Paul Wegener, 1920), or the inventor Rotwang in Metropolis (Fritz Lang, 1926), among others. For classical horror, see our study "The Corpse and the Body in Hollywood Classical Cinema." The Body Snatcher (Val Lewton/Robert Wise, 1945) in Archivos de la Filmoteca, 14, 1993: 264-277).
} 
better clarify. This digression shall bring us to two points we refer to as symbolic of the corporeal and of the disciplines that deal with the body, namely: the history of illness and the progress of genetics.

With respect to illnesses, it would be fitting to consider them, as does Susan Sontag in two brilliant books, in the light of the metaphors that have accompanied them and that have helped transmit their social message, often in contradiction to their actual symptoms or pathological structures (Sontag 1977, 1988). Since it is a question of symbols, Sontag succinctly analyzes the metaphorical interweaving to which illnesses considered mysterious are subjected and the stigmatizing nature of those that produce dehumanizing effects: leprosy, which can be allegorically read as corruption; rabies, used to express the fantasy of animalization; cholera, some of whose symptoms seem to forebode post mortem. decomposition; or cancer, which incarnates the ferocious metaphor of energy-ultimately characterized by expansion, speculation and anomalous growth similar to the economic metaphors of late capitalism. It is curious, though, those scientific discoveries do not annul the metaphoric effects; they merely displace them onto other objects. This is, for example, the metaphoric drama (there is a real one, of course) of AIDS experienced, Sontag shows, as a return to premodern illness and has yet to acquire a convincing and exorcising form of psychologization. ${ }^{4}$ The list could go on but we shall limit ourselves to consider the pathological within the symbolic order-in the Lacanian sense-instead of just diagnosing it. And, in this operation, language - the decisive instrument of Medicine-turns out to be full of evocations and highly thought provoking.

With respect to our second digression, the symbolic effect we experience day to day and whose unfolding is genetics, it is easily detected that the research and advances in artificial insemination, in-vitro fertilization, test-tube babies, post-menopausal births, sperm freezing, or implanting ovaries in different places in the body etc., far from being a

\footnotetext{
${ }^{4}$ Keep in mind, for example, what Sontag showed concerning tuberculosis: its aestheticization on the part of romanticism was so significant that even the tuberculoid model of body became fashionable for the aristocracy. All this was produced against the presence, to take an obvious example, of the stench of the tubercular breath that very likely accompanied decomposition. Why has the notion of bodily consumption given over to imaginings so disparate as the aestheticization of tuberculosis and the mythological references that AIDS carries with it? This is not a question of or for Medicine, but is rathe1 one of the symbolic productions of our universe of meaning.
} 
scientific problem, deal with the most profound part of human desire, as the famous case of the surrogate mothers clearly shows. Let us say, then, that this is but the last formation, with its marked narcissistic effects, of the failure of Medicine to understand the human body and sexuality itself. As Silvia Tubert has accurately demonstrated, "medical discourse is condemned to ignore sexuality and even vital essential functions whenever they go beyond the conservation of life (nutrition, breathing, etc.) and constitute a source of pleasure and suffering as well, therefore taking on meaningful values that do not end with its materiality" (Tubert 1992: 144). Now, with the advances of genetics, the symbolic universe (and not only that of science) is again invoked inasmuch as it points to questions such as sexual difference or paternity and maternity, which are not merely biological problems, but also symbolic ones. In sum, genetics is stirring up the foundations of some of the fundamental symbolic mechanisms of our civilization. And our postmodern universe-the very one that presses the accelerator of a genetic imaginary-is constructing models with which it can identify.

In this context, it won't take us long to notice a flagrant clash between two fantasies of body representation: on one hand, the glorification on the part of publicity with its plastic, flexible, without an ounce of fat or excess, muscular yet lean representation of what we might call in Freudian terms the ideal body ${ }^{5}$ (my emphasis); on the other, the mangling of the body mentioned above presented in modern horror films. What is continually surprising is the symbolic interlocking that awakens here from a dream, infecting more and more aspects of our modern life: in a world where plastic surgery promises the realization in our own bodies of the form we long for (as in the expression: "building my body to fit my own desire"), people are brought up short by their own perpetually indecisive desire. When almighty genetics offers us scot-free the choice of sex and liberates sexuality from reproduction once and for all, it appears that the symbolic relationship between the sexes has been dangerously erased; when experiments in which animals are crossed with humans are a scandal for bioethics, urges take on the form of bestial fantasies. What is at stake

\footnotetext{
${ }^{5}$ It would be worthwhile to compare this leanness of the postmodern ideal body with the unblemished absence of corporeality of the actresses in Hollywood Classical films: the aura enveloping their faces made them incarnate their 'soul;' this is in contrast to what happens with many male actors whose faces often appeared with a trace of the Real-a wrinkle or a scar-whose symbolic effect signaled some harsh and unbearable past history.
} 
is a series of anthropological keys that not long ago were a basis for meaning in our civilization. We consider postmodernism, then, the state of culture in which these binary oppositions disappear without being substituted by others in a stable manner.

\section{Cronenberg and Metamorphosis}

No other contemporary filmmaker gears his products toward the destiny of the body like the Canadian David Cronenberg. And the critics have not overlooked this. To cite only a few recent texts, Serge Grünberg in his work pointed out the imposing presence of the viral and degeneration (Grünberg 1992); Stanley Wiater notes to what point Cronenberg became the myth of the cineteratologists (Wiater 58); Adam Knee refers to the relationship between corporeal decay provoked by AIDS and Seth Brundle's suffering in The Fly, emphasizing the contrast to the cult of the body during the eighties (Knee 1992) and Mary B. Campbell already stressed some time ago the uniqueness of this film-maker in "seeing diseases from the point of view of the disease itself" and the fear of the body itself as uncanny (growth, profusion, abundance) (Campbell 1984). Cronenberg himself has on many occasions rejected the allegorical interpretation that considered his films as an expression of AIDS; he did affirm, however, the presence of the corporeal in relation to the allegorical. He commented on The Fly, "That's why I don't want it to be AIDS, truly .... It's an examination of what is universal about human existence, and that hasn't changed .... AIDS is tragic. But, beyond it all, I'm digging deeper. We've all got the disease-the disease of being finite. And consciousness is the original sin: consciousness of the inevitability of our death" (Rodley 127).

Now, if the above quote approached the metaphysical, we should not forget that metaphysics is the result here of a confrontation with the real which Cronenberg's films do not shield us from in any way. One can clearly see how literally Cronenberg reads the decay of the body unconnected to any human temporal alibi: "There's no such thing as an old person. There's a person who has been broken on the rack of pain and infirmity, but there's really no old person. When someone dies at eighty, it's the death of a young person. I see that" (128). He speaks as well about this consciousness of the body referring to the confrontation between body 
and soul in Medieval Catholic imagery: "Catholic imagery of the Middle Ages is very body-conscious and very obsessive, all for the same reason: the illumination of the mind, the spirit, the soul versus the body. For different reasons, but it's the same philosophical discussion. You could be a Catholic and be obsessed with torture, pain, decay and disintegration, as the entire medieval world was in all its forms" (129).

Let us omit a long list of references and return to the search for the crux of motives that interest us today: science and the scientist, the body and its atomization, and specifically, the hybrid between animal and human. In order to approach such an objective, we propose a study of metamorphosis. This theme has its roots in Classical culture and art, linked to the mythology in Homer and Ovid, where it functioned allegorically; it is a generator of monstrosities which would go on to become the gargoyles in our Gothic cathedrals. The nineteenth century makes it vacillate, depending on sudden fevers, transitory deliriums that disappear the morning after, attributing it to momentary loss of sanity. In Kafka, finally, it appears in its full meaninglessness, in its most radical absurdity, without mention of any psychological or biological cause whatever. It would be fascinating to trace this itinerary replete with meanderings and producer of freaks. Whatever that might be, what is certain is that if this is a recurring figure it is because it fearlessly assaults the symbolic edifice that anthropology showed to be the guarantor of a system of culture: metamorphosis represents that instant when the founding distinction between the human and the animal is called into question, suspended. Once again we are facing the problem we were showing in regard to biology and genetics: that which is called on to be the foundation of the edifice becomes in significant and chaos threatens to take hold of our universe. Moreover: that meaning which is held in suspense-the symbolic_-knocks on the doors of biology to find there the best inspiration (rigorous or not, that is irrelevant) that allows it to mesh with the human body, with the flesh, with the most painful flanks of the sign. As Freud said, anatomy is destiny. ${ }^{6}$

In a film such as The Fly the tragedy of the progressive downfall of the body is lived from within it, with no dramatic conversion whatsoever,

\footnotetext{
${ }^{6}$ Because of this intervention of the genetic and biological level, and because of the extreme corporeality where the drama unfolds, The Fly should be distinguished from the whole throng of films where metamorphosis is brutally imposed onto the eyes, omitting none of the violence to the body, but in animist or neoanimist code. Suffice a few examples such
} 
and it does not end up being a transcendental narrative. Here the fantasy of unrecognition is carried to the limit and the identity of the end result is impossible to determine: the hybrid has dissolved identity.

\section{A Never-Ending Itinerary}

Actually, The Fly - a remake of a film directed by Kurt Neumann in 1958 - presents a unique trajectory: the narrative has become embedded, like a parasite, in the human body. Let us recall the plot in detail, in the way it is written in the script by Charles Edward Pogue and Cronenberg himself. The brilliant researcher Seth Brundle (Jeff Goldblum) drives the journalist Veronica Quaife (Geena Davis) to his laboratory. Dedicated to the study and experimentation of teleportation, that is, the disintegration and reintegration of objects through space, Brundle persuades Veronica not to print the discovery in the magazine Particle, directed by her former lover, until it has been properly perfected. Motivated by Veronica's absence, Seth, drunk and in the clutches of jealousy, tries out his experiment and teleports himself. Unfortunately a fly gets into the chamber and during the process of reintegration, the computer, finding itself with two different genetic patterns, decides to fuse them. Thus begins Brundle's slow metamorphosis which will dramatically conclude with his becoming unrecognizable and his ultimate destruction.

The first notable characteristic of this process of metamorphosis is how soon it begins. Cronenberg hardly allows time for the narrative to get started, for unfolding story lines and secondary characters, even for those useless accidents of narrative economy that Roland Barthes called the "effects of the real." Instead, scarcely a half hour into the film Brundle will have abandoned his games with things or animals and have taken the definitive step toward his transformation. It would be worthwhile to follow the distinct phases, as if it were a question of narrative inflexions, since the emphasis is not placed-in contrast to the films of metamorphosis with an animist bent, lycanthropy in particular-on the scopic attraction

\footnotetext{
' (con't) as An American Werewolf in London (John Landis, 1981), The Howling (Joe Dante, 1981), The Howling II (Philippe Mora, 1984), The Howling III (Philippe Mora, 1987), The Company of Wolves (Neil Jordan, 1985), Cat People (Paul Shrader, 1982), Silver Bullet (Daniel Attias, 1985), Demons (Lamberto Bava, 1985), Demons 2 (Lambetto Bava, 1987) and the list goes on and on.
} 
that is produced with each transformation, but rather on an unbridled race toward the unrecognition of his own body, his growth and forms.

Thus, the first manifestations are imperceptible to the eye. Uncommon physical strength leads Brundle to nocturnal gymnastics on the parallel bars. It is a question no doubt of excess energy, detectable in his perfect moves and agitated breathing. This symptom is followed by an apparently unprovoked nervousness, recognizable in repeated movements, compulsive acts and an outrageous expression of narcissism. We have here, in both cases, a series of symptomatic manifestations: the interior produces signs visible to the exterior, but these signs are actually metonymies of the change taking place. This change is not, however, discernible or diagnosable. The reactions that are to follow, without abandoning status as symptoms soon preclude, through their excess, any attempt at a psychological interpretation. ${ }^{7}$ Hence arises his sexual hyperpotency, an untiring energy that leaves Veronica both surprised and exhausted. This has nothing to do with the motion of his desire; it is rather, the effect of an unstoppable urge. And, immediately afterwards, this enigmatic physical strength is unleashed as Brundle breaks in two the arm of a tough-looking character. As we can see, in both cases the excess energy finds another on which to unleash itself: whether it be for pleasure or for destruction, we can call it jouissance. His energy can no longer be used up within himself and the other is, we know, one of the sources for narcissism and its exercise.

However, this exteriority, even if it is only duality, soon comes to an end, and from that moment on, Brundle's experience centers on his body, without being able to get out of it. The confrontation awaiting Brundle is beyond narcissism, that is, beyond the mirror, the place where his own self-image, and that of the other, joyously came together to form the subject. When that mirror is broken, what remains is the body, a mass of muscle and organs, with no possibility of uniting, no recognition, and no imaginary to hang onto. The impossible that fractures the narrative in which Cronenberg finds himself is that which Jacques Lacan referred to as the body in pieces (corps morcele). ${ }^{8}$

\footnotetext{
${ }^{7}$ Observe that in Cronenberg's films there is no unconscious that acts: what pertains to the formations of the unconscious is radically adopted by the body, where it lives in that form of the real that is the torn apart, inhabited, decaying body.

${ }^{8}$ See next page.
} 


\section{The Fall of the Body}

We have just said it: everything in The Fly possesses a full material, corporeal dimension. Looking in the bathroom mirror, Brundle suffers the first manifestation of how his body is coming apart; with a light touch one of his fingernails falls off and a disgusting liquid oozes out. His face seems to be stained with patches of unknown origin. Veronica, frightened, mentions his bad odor while revealing to him the results of the chemical analysis of the mysterious hairs that appeared on his back: these hairs are not human, they are similar to insect hair. With the uneasiness caused by the incomprehensible, Brundle reaches for an explanation that is shortly shown to be naive in comparison to his tragic destiny: "I'm dying," he says in a dramatic expression, trying to find meaning, an end to, or an objective for the disease. We will later see how, in his anguish, Brundle will wonder what the disease wants (my emphasis). He studies in what way it reveals its aim. In the absence of a calming medical metalanguage and the non-existence of a clinical framework capable of naming, locating and exorcising his terror, there is nothing left except the anguish of a body that is decaying without an understanding of why. And the doubts seem to suggest the most complete dehumanization, out of which come questions with no answers: the non-human hairs plucked from his back,

\footnotetext{
${ }^{8}$ For Jacques Lacan, narcissism is what conceals the dismemberment of the body. For this reason, this author always insisted on the tension between the body in pieces (corps morcele) and alienation in the image, the crux of an opposition he firmly maintained between the real and the imaginary. See the first and nearly unmodified formulation of his theory in "Le stade du miroir comme formateur de la fonction du Je telle qu'elle nous est révélée dans l'expérience psychanalytique" in Ecrits I, Paris, Seuil, 1966. Freud, on analyzing the 'Emmy case' in his Studien iiber Hysterie, confronted that so characteristically hysterical phenomenon which is disgust. In a recent work ("Lo imposible de soportar en la vida cotidiana" [That which is impossible to bear in everyday life]), a document for the $\mathrm{X}$ Jornada del Campo Freudiano en España, Barcelona [Tenth Congress of Freudian Studies in Spain, Barcelona], March 1992, Dolores Castrillo, Gustavo Real and Piedad Ruiz put it this way: "What is the meaning of this decomposing flesh? None other than the fall of the body from its unified state to its fragmented, real, de-eroticized state" (32). We can imagine, in the light of this theoretical implication that Cronenberg's entire film moves within that de-eroticized realm of decomposition and atomization of the body. We find ourselves in a place opposite to that which Jean Baudrillard joyously celebrates in De la séduction, Paris, Denoël, 1979.
} 
are they an expression of the animal embedded in his body? The bad odor, is it perhaps an effect of an interior cadaverous decay? Or even a prophecy of impending decomposition? ${ }^{9}$

At this tragic moment, the carnal crudely imposes its law, impeding the slightest metaphorical sidetracking. The answer to Brundle's anguishing question paradoxically comes to him not from his bodywhich does not speak except through the pure image of horror-but from the most digitalized of signs, namely: a computer image. From the interior of the sophisticated computer language emerges something that the human eye cannot see: the Real. Brundle interrogates, therefore, the computer. He demands an answer he could not have expected to find through other means. He undoes the process of disintegration and reintegration he underwent, through each and every one of the phases imperceptible to the human eye: and there, magnified to the point of horror, appears the digitalized figure that lives inside his body, unrecognizable, undetectable, yet eating away at him causing his irrevocable fall: a fly. Represented graphically, amplified, it is there and will never be seen again because, like the Real, it is not only invisible, but also impossible. ${ }^{10}$

The fly, impossible to perceive in the body given that it is covered up is, nevertheless, detectable in a diagram. That is what is uncannysomething of the real is insinuated within a body; the eye, in spite of it all, can sense it without recognizing it. And here, too, lies the paradox of the real: it is a blueprint, an abstraction, that which gives proof of its existence. Now, the place where it embeds itself is not in the diagram (it only positions it like a scanner): it is in the human body itself. The fly does not exist except as a fleeting moment that the computer has frozen and analyzedthe point where it penetrated Brundle's body to later disappear. The answer to the question of the insect and its relation to the human is terminal: fusion at the molecular-genetic level. That fly which we saw digitalized in a diagram has disappeared. And for the same reason, that other body that looks like Brundle is also disappearing; or rather, we see the collapse, that is, the break down of its form, its Gestalt.

\footnotetext{
${ }^{9}$ Michel Foucault pointed out the close relationship between the constitution of modern medicine and the elaboration of a closed metalanguage in Naissance de la clinique. Une archéologie du regard médical (Paris, P.U.F., 1963).

${ }^{10}$ This is how Lacan describes the Real.
} 


\section{An Impossible Narcissism}

An ellipsis occurs. Four weeks have gone by and the only news we have about Brundle is through a metonymical representation of what has happened: the mutation of his voice. It is then when the scientist observes his malady through the transformations of his body and shows, with sarcasm, horror, disgust and archeological zeal all at the same time, his scientific tenacity: "I am sick and it may be contagious. I wouldn't want to infect you," he says to Veronica, "and it's speeding up. It doesn't stop. Every day there are changes. Every time I look in the mirror I see someone different, disgusting, repulsive." This is a dramatic observation whereby the first representation through which narcissism is congealed-the unifying image of the body itself-comes apart and is transformed, becoming unrecognizable.

In effect, nothing could be more wholly anti-melodramatic: Brundle's legs are twisted; by this time the strange things that invade his body are manifested as the superposition (the fusion) of the animal and the human. But, what is Brundle? Is he perhaps a fly-man in the same way we speak of the wolf-man? No, since the wolf-man is represented in his end moments (either a wolf-as a metaphor-or a man; rarely at the moment of metamorphosis). Brundle, on the other hand, is something mixed, in constant decomposition, unanalyzable, indescribable. The only certain thing is that his human image and his body are being demolished and his very face seems to be coming apart, looking uncannily like that of an insect. Hence, the computer baptizes him again as Brundlefly, that is, "something that never existed," something located halfway between human and animal. With the cellular revulsion and the oozing out of a disgusting drool, any trace of melodrama disappears. And this accordingly occurs because we find ourselves faced with the repulsive - that limit which Kant imposed on art in his Critique of Reason and what Eugenio Trias aptly reminds us of:

The uncanny constituted the condition and limit of the beautiful ..., it must be present in the form of absence, it must be veiled. It cannot be unveiled .... The arts of today-cinema, narrative, painting —are on a dangerous path: they are trying to stretch that limit and that condition, revealing it in such a way that the aesthetic effect is preserved. (Trías 17-18) [our translation] 
We might doubt whether the aesthetic effect Trías discusses is preserved in modern horror films. "Art," he continues,

is fetishistic: it is located in the vertigo of a position of the subject which is 'on the verge' of seeing that which cannot be seen; and that vision, which is blindness, is perpetually deferred. It is as if art-the artist, the work, the characters, the spectators-were situated in a strange position, always just before a revelation that is not produced because it cannot be produced. Hence there is no 'last word' on the work of art. It makes that 'just before' moment into a space of relaxation and dwelling: it lasts exactly as long as the fiction does. (43)

We may wonder, then, if current horror films (The Fly in particular) stretch this border-closing in on this ultimate, unrepresentable scene. Moreover, keeping in mind that this scene is unrepresentable, it is very possible that the aesthetic experience is damaged, broken or destroyed by that operation of approaching the limit.

Let us return to this representation of the repulsive, the truly tragic. One of Brundlefly's ears falls off, and his repulsive vomit is, moreover, functionally corrosive-it liquefies solid foods which he is incapable of ingesting... Here he summarizes the idea of transformation, "I' $m$ turning into something that has never existed: Brundlefly." The important thing is not, we must insist, the end result but rather the process and its effect of unrecognizability (emphases mine). What is actually at play is the degradation of the human; or more specifically, the degradation of the flesh. ${ }^{11}$ As we mentioned above, melodrama cannot penetrate here, in spite of its attempts: trying to be compassionate, Veronica hugs what was previously her lover, but she can only feel paralyzed by horror and disgust. The treatment of the shot/reverse-shot that shows the characters emphasizes the indecision of that which enters into opposition: man/ woman, human/animal, and monster/human ... In the end, all these oppositions dissolve because none of them can give an account of Brundlefly's ineffable, boundary position.

\footnotetext{
"Suffice it to recall that disgust, in relation to human flesh, is the explicit theme in an unending number of horror films in recent times: the mechanical cannibalism of the living dead in Night of the Living Dead (1968), Dawn of the Dead (1979) and Day of the Dead (1986), all directed by George A. Romero; the slaughter metaphor applied to the human body in Blood Dinner (Jackie Kong, 1987) and, above all, The Texas Chainsaw Massacre (Tobe Hooper, 1974) and The Texas Chainsaw Massacre II (Tobe Hooper, 1986). And, of course, all the sequels or imitations these cult films have inspired.
} 


\section{An Uncanny Archeology}

It would seem impossible to go any further down the road to the loss of the image of the body than what we see in the last sequences of The Fly. And yet, Cronenberg introduces a new phase, that is, an unplausible twist to the process: Veronica discovers that she is pregnant by Seth. The terror that overtakes her expresses the nausea for what she carries in her body. She then suffers a nightmare where she miscarries a sticky, oblong bug. Let us go over the situation in detail: if Seth is a flyman, with the two components, not superimposed, but rather fused together at the genetic-cellular level, what will be the form and entity of the being gestating in Veronica's body and produced by Brundle's sperm? In answer to such an intricate complication The Fly II. A New Generation (Chris Wallas, 1989) gives a reply of a melodramatic nature and tinted by a fairly unelaborated social discourse. We could say that The Fly begins where other films end; films such as It's Alive (Larry Cohen, 1973) and its various sequels or Baby Blood (Alan Roback, 1989) where genetic monsters fatally end up turning into demon murderers, setting up an entirely conventional narrative of pursuit and destruction.

Brundlefly has made a decision: to bequeath a testimony, to leave behind a memorial, and consequently, he uses two contradictory but complementary procedures to do it: on the one hand, he makes a video in which he notes his transformations and metamorphoses, his decomposition. As Wim Wenders stated, regarding filming the last moments of Nicholas Ray in his Lightning Over Water (1980): "The eyes see with pity, but the camera does not." Seth's procedure is all the more surprising, then, and demonstrates the supreme attitude of the scientist: he saves in drawers (a delicious fantasy) the parts that have fallen off his body, irreverently and ironically calling an uncanny archeology, or in his words, "The Brundle Museum of Natural History"- a fitting expression of the history of the man in an inverted sense, that is, not of his growth, but of his decomposition. The object of the scientist is deposited in the emptiness of anguish and what is at stake is his body as it is subjected to decomposition. Thus, science has never lived so apart from-and paradoxically so united to-human suffering. Science imposes its gaze on a battered and bruised object, which it can still observe and analyze; he does it to leave a testimony that will outlive him. Never has the subject of science been so close to its object, not even in magic or animist practices. 


\section{A Dream without an Unconscious}

"I dreamed I was an insect dreaming it was a man." Thus says Seth, lost in the mirage of his condition. However, his body once again will return him to a world in which sophisticated exercises of thought are impossible. At the end of this tragic itinerary, and after his battle with the antagonist Stathis Borans (John Getz), Seth is fully unrecognizable and has been reduced to a pile of flesh. Here and there are bits and pieces that look like Seth or a fly: what was brewing inside has surged out. And, in spite of all this, the terrible tale does not end here. Brundle offers Veronica a new and ultimate fusion-the ideal family. It is a repugnant metaphor of beatific home bliss, whereas this is nothing other than a jumble of flesh. Brundle comes apart at an incredible rate. His skin falls off as new tissues are generated from within; bloody layers without shape or form come out one by one, unrecognizable to the eye-of the spectator-which is held in fascination without being able to decipher what there is-or was-of the human.

This is the moment when the supreme fusion between Brundle and the teleport itself occurs. It is no longer the animal and the human which coexist in this body that destroys and then carcinogenically regenerates itself, ${ }^{12}$ but also the living and the inert. The result of this final fusion is not unrecognizable flesh but rather a malformation and what was previously human vanishes for good. And Seth, a brutal insect, makes the only melodramatic gesture in the whole film. He puts the barrel of the gun Veronica is holding to his head, begging her to put an end to his absurd torture. The bloody mass (is there by chance any name anthropology could borrow from language to describe this object?) bursts into a thousand pieces, making that tragic object-our very own body (which for us in postmodernity is both strange and familiar, hence uncanny)-tremble as well. ${ }^{13}$

\footnotetext{
${ }^{12}$ If we were forced to put a finger on the metaphors of disease put into play here, we would say that two contrary formulations join here: the one that refers to bodily consumption alludes to AIDS, and the other points to the unchecked growth alludes to cancer. Both can be found in the corporeal literalization we see in The Fly.

${ }^{13}$ We should also like to note here that the monsters Cronenberg puts into his films start out as fantastic and become gradually more realistic, while continuing to be embedded within human anatomy. An extreme example of this can be seen in Dead Ringers (1988), where the delirium is connected to the monstrous eruption (that is, in its monstrosity, in its Real) of the female body seen by two twin gynecologists.
} 


\section{Works Cited}

Baudrillard, Jean. De la séduction. Paris: Denoël, 1979.

Campbell, Mary B. "Biological Alchemy and the Films of David Cronenberg," in Planks of Reason. Essays on the Horror Film. Barry Keith Grant, ed. Metuchen/ N.J/London, Scarecrow, 1984: 307-320.

Foucault, Michel. Naissance de la clinique. Une archéologie du regard médical. Paris: P.U.F., 1963.

Grünberg, Serge. David Cronenberg. Paris: Etoile/Cahiers du cinéma, 1992.

Knee, Adam. "The Metamorphoses of the Fly," in Wide Angle 14-1, 1992: 20-34.

Lacan, Jacques. Ecrits I. Paris: Seuil, 1966.

Lévi-Strauss, Claude. La pensée sauvage. Paris: Plon, 1962.

-. Myth and Meaning. Toronto: University of Toronto Press, 1978.

Rodley, Chris ed. Cronenberg on Cronenberg. Toronto: Alfred A. Knopf, 1992: 127-128.

Sánchez-Biosca, Vicente. "The Corpse and the Body in Hollywood Classical Cinema. "The Body Snatcher" (Val Lewton/Robert Wise, 1945) in Archivos de la Filmoteca, 14, 1993: 264-277.

Sontag, Susan. Illness as Metaphor: New York: Anchor Press, 1977. -, AIDS and its Metaphors. New York: Anchor Press, 1988.

Trías, Eugenio. Lo bello y lo siniestro. Barcelona, Seix Barral, 1982.

Tubert, Silvia. "Desórdenes del cuerpo," in Revista de Occidente № 134135, 1992: 138-147.

Mujeres sin sombra. Maternidad y tecnología. Madrid: S. XXI, 1991.

Wiater, Stanley. Dark Visions. Conversations with the Masters of the Horror Film. New York: Avon, 1992. 

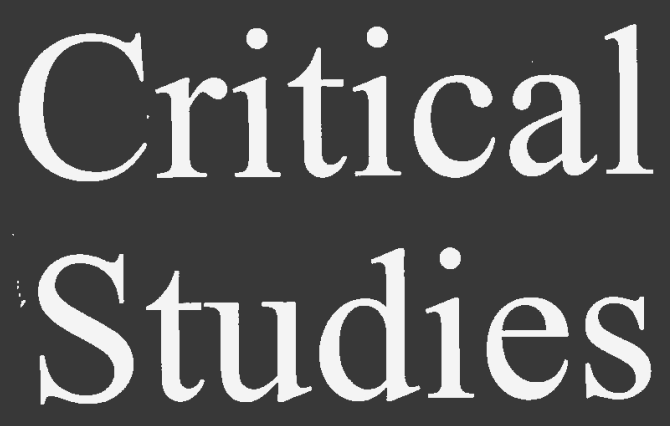

\section{Unforeseeable} Americas: Questioning Cultural Hybridity in the Americas

Edited by Rita De Grandis and Zilà Bernd 